\title{
A DECADE OF STATE LABOR LEGISLATION 1937-1947*
}

\author{
HaRRy A. Mirlis $\dagger$ AND Harold A. Katz $\ddagger$
}

$\mathrm{A}^{\mathrm{p}}$

DECADE has elapsed since Wisconsin in 1937 became the first state to adopt a labor relations act. Since then no fewer than forty-two states have passed legislation affecting industrial relations and labor organizations. Ten of these states have adopted labor relations laws comparable to the federal statutes of $1935^{\mathrm{x}}$ and $1947 .^{2}$ The others singled out some specific problems which have been dealt with on more of a piecemeal basis. The fact that such a large number of states have seen fit to regulate aspects of labor union activity indicates a widespread belief on the part of state legislators that an overriding public interest is involved in labor-management relations. Certainly there has at no time been such widespread legislation in this field among the states.

The Wagner Act was designed to give more nearly equal rights to management and to labor by limiting the activities of the former when they transgressed the rights of labor, as they so frequently had. But the common and statute law relating to form of organization, admission and expulsion of members, and related matters were still regarded as within the proper province of the states except in so far as the regulation of interstate commerce and the granting of restraining orders by the federal courts were concerned. The behavior of unions in the use of pickets, the boycott, etc., was otherwise left to the states, where it then was. Moreover, a closed-shop proviso found in Section 8 (3) of the Wagner Act took its form in order to leave state laws undisturbed as much as possible.

The imposition of unfair labor practices upon management and requiring an employer to bargain collectively with the majority representative of his employees could of course have been expected to serve as an invita-

\footnotetext{
* The analysis herein made was undertaken in conjunction with a study of measures in the Congress culminating in the adoption of the Labor-Management Relations Act, 1947. Grateful acknowledgment is made by the authors to the staff of the Review for assistance rendered in the preparation of this article.

† Chairman emeritus of the Department of Economics, University of Chicago, and formerly Chairman of the National Labor Relations Board.

$\ddagger$ Member of the Illinois Bar.

I National Labor Relations Act, 49 Stat. 449 (x935), 29 U.S.C.A. \& $15 x$ et seq. (1942).

${ }^{2}$ Labor Management Relations Act, 29 U.S.C.A. § I5I et seq. (1947).
} 
tion to regulate unions in respect to their responsibilities and conduct. Indeed, such legislation had been proposed at the hearings on the Wagner Bill but had not been adopted. However, after unions had been greatly strengthened by the federal act, which was designed to, and did, encourage collective bargaining, the states themselves set about defining the obligations and restricting the activities of labor unions. It is interesting to note that from the great mass of state legislation came many of the provisions of the Labor Management Relations Act of I947. Congressmen had not been unaware of what had been transpiring in their home states. Moreover, they were susceptible to the same pressures which had resulted in legislation in their constituencies.

The year I937 saw the emergence of "Baby Wagner Acts" which guaranteed to employees the right to organize, to join or assist labor unions and to bargain collectively. These protective statutes were designed to encourage organization and collective bargaining. The year 1939 , however, witnessed a reversal in this trend, with the adoption in certain key states of statutes designed to restrict employee activities and union methods, even while sometimes accompanied by less stringent prohibitions against employer unfair labor practices. The I943 sessions of the state legislatures resulted in a great volume of labor legislation, and, notably, the beginning of widespread regulation of the organization, "internal affairs" and procedures of labor unions. The banner year in state labor legislation was, however, 1947 , when thirty states enacted statutes regulating or restricting union activities. Public reaction to the post-war strike wave resulted in the adoption in eleven states of laws regulating disputes in public utilities, the banning in six states of strikes by public employees, as well as a large body of legislation seeking to obviate "unnecessary strikes"- such as those resulting from jurisdictional disputes-and to limit the area of labor disputes by prohibiting secondary boycotts and by restricting picketing and other strike activity. It was in 1947 also that the movement for prohibiting or regulating union security agreements reached its peak, with fourteen states adopting legislation of this type.

It is notable that the bulk of the regulatory legislation during the last decade, and especially in the earlier forties, was to be found not so much in the great industrial states of the East and of the Middle West as in the relatively non-industrial areas of the nation. Thus the great wave of anticlosed-shop legislation has been found without exception in predominantly. agrarian, non-industrialized states, where collective bargaining and union security provisions are relatively infrequently found. The states legislating, and the communities within them, have generally been active- 
ly interested in furthering industrialization, but nevertheless generally reacted against the resulting "labor troubles" which more or less inevitably developed. Unquestionably there was also some feeling that if they could succeed in keeping unions out, industry would be attracted in. Frequently "yankee" management has sought to rid itself of problems connected with unionism and to profit from the reduced costs to be obtained from lower wages and the not infrequent subsidies to be had from relocating or expanding into southern or other non-union territory. Established unions, like the Textile Workers, have, of course, foreseen only loss from the consequent unequal competition, followed by labor disorganization, and have sought to extend their organization to the new territory. Hence, considerable conflict has developed in these semi-industrial states, in which farmers and businessmen generally can be expected to join forces against unions. Such states, and the hinterland in the more industrialized areas, have largely constituted the "industrial frontier" in which union organization and union procedures have been and are giving rise to much of the so-called anti-union legislation.

While the common law and early statutes regarding union activity are not the subjects of this study, they should not be entirely forgotten. There was of course law governing strikes, picketing and boycotts even before state legislators became interested in the subject. But a tremendous amount of legislation has been enacted during the last ten years to cope with presumed problems arising in the field of industrial relations. This has codified, modified, amended and greatly extended the rudimentary law which the courts, municipalities and earlier state legislatures had created.

Of the statutes enacted in the field of labor relations during the last decade, the most comprehensive have taken the form of labor relations acts administered by state boards or commissions. These ambitious attempts at enunciating a public policy regarding industrial relations will be the first subject of inquiry. Following this, a cross-section view will be taken of all the labor relations legislation enacted during the past decade - piecemeal enactments as well as the broader statutes-first, to examine the extent of regulation of certain union methods and then, finally, to analyze that body of legislation regulating the union organization itself.

\section{PUBLIC POLICY EXPRESSED IN STATE LABOR RELATIONS ACTS}

The most comprehensive formulation of public policy regarding collective bargaining and union activity is found in the ten states which have 
adopted labor relations acts. ${ }^{3}$ These laws proclaim a policy of peaceful industrial relations and grant employees the right to collective bargaining. At the same time, each sets up an orderly procedure for the selection of a bargaining representative. The acts set forth provisions by which the public policy is to be effectuated, and a labor relations board or commission is established to make the policy effective.

The first state to adopt such legislation was Wisconsin, ${ }^{4}$ whose Baby Wagner Act was passed soon after the constitutionality of its federal prototype had been upheld by the Supreme Court. In rapid order, in the same year, similar statutes were passed in four other states-Massachusetts, ${ }^{5}$ New York, ${ }^{6}$ Pennsylvania ${ }^{7}$ and Utah. ${ }^{8}$ Although like enactments were expected in many other states, ten years later only New York still had on its books its little Wagner Act substantially unmodified, all the rest of the states mentioned having joined the movement toward "equalization" and more extensive union controls. Subsequently only two other states-Rhode Island in $194^{I^{9}}$ and Connecticut in $1945^{\mathrm{ro}}$ - adopted Baby Wagner Acts. In many other states such bills were introduced but failed to pass. For example, in the single year of 5945 , when Connecticut adopted a statute modeled on the Wagner Act, it is reported that such measures were introduced, but died in the legislative hoppers of five other states.

Since I939, when Wisconsin repealed, ${ }^{\mathrm{II}}$ and Pennsylvania drastically amended, ${ }^{12}$ her Baby Wagner Act, and Minnesota ${ }^{13}$ and Michigan ${ }^{14}$ passed labor relations acts, the trend in state enactments has been rather steadily away from the protective type of labor law and towards legislation which restricts rather than enlarges labor's "rights.". The acts generally watered down the employer unfair labor practices found in the

\footnotetext{
3 Colorado, I943; Connecticut, 1945; Massachusetts, 1937; Michigan, I939; Minnesota, 1939; New York, I937; Pennsylvania, I937; Rhode Island, 1945; Utah, I937; Wisconsin, 1937. While the Kansas statute of 1943 and the Delaware enactment of 1947 are fairly extensive in scope, it is not felt that they properly fall under the heading of labor relations acts. The use of that term is here confined to acts administered by labor relations boards or commissions.

4 Wis. Stat. (Brossard, r943) $\$$ Irr.or et seq.

5 Mass. Ann. Laws (1942) c. I50A, \& I et seq.

6 New York Labor Law (McKinney, I940) art. 20.

7 Pa. Stat. Ann. (Purdon, I94I) tit. 43, \& 2 II.I et seq.

${ }^{8}$ Utah Rev. Stat. Ann. (ז943) $\& 49-\mathrm{r}-9$ et seq.

9 R.I. Gen. Laws (194I) c. 1066.

ro Conn. Gen. Stat. (Supp. I945) §933h et seq.

"Wis. Stat. (Brossard, 1937) $\S$ Irr.or et seq., repealed by Wis. L. (r939) c. 57 .

$12 \mathrm{~Pa}$. Stat. Ann. (Purdon, x94I) tit. 43, \$\& 2Ir.I-2II.13.

${ }_{13}$ Minn. Stat. (Henderson, I945) \& 179.01 et seq.

14 Mich. Stat. Ann. (Henderson, Supp. 1946) $\$ 17 \cdot 454-1$ et seq.
} 
federal statutes, if, indeed, they included them at all. At the same time they usually "equalized" the act by including employee and union unfair labor practices. This type of statute has been adopted de novo or by amendment in Wisconsin, ${ }^{15}$ Pennsylvania, ${ }^{16}$ Minnesota, ${ }^{17}$ Michigan $^{18}$ and Colorado. ${ }^{19} \mathrm{~A}$ most significant and characteristic feature of most of the restrictive acts is that the right of employees specifically includes, not only the right to engage in self-organization and collective bargaining, but also the right to refrain from doing so-which was, of course, always implicit. It was in the Wisconsin Employment Peace Act of 1939 that this provision, which has been embodied in the Taft-Hartley Act, ${ }^{20}$ first found expression..$^{2 \mathrm{x}}$ Minnesota denied the benefits of the protection of her Act to any employee, employer or labor organization violating any of its provisions. ${ }^{22}$ Wiscon $\sin ^{23}$ and Colorado ${ }^{24}$ did the same but left it to the board's discretion as to whether it would suspend the union's "rights, immunities, privileges or remedies" under the law for a period not exceeding one year. Representation procedure is provided in all of the ten labor relations acts, establishing an orderly method for the selection of a bargaining representative for an appropriate unit. An important departure from the NLRA procedure is found in four of the states with restrictive statutesColorado, ${ }^{25}$ Minnesota, ${ }^{26}$ Pennsylvania ${ }^{27}$ and Wisconsin ${ }^{28}$-where the board's certification of a bargaining agent is made subject to judicial review. Such an amendment to the NLRA was considered recently by the Congress, but was not included in the Taft-Hartley Act after Chairman Herzog had argued that with a provision like this, "Employers interested in delay and minority unions disgruntled at the result of an election could postpone collective bargaining indefinitely." ${ }^{29}$ In these four states the em-

${ }_{15}$ Wis. Stat. (Brossard, I937) $\S$ Irr.or et seq., repealed by Wis. L. (1939) c. 57 .

${ }^{16} \mathrm{~Pa}$. Stat. Ann. (Purdon, I94I) tit. 43, §§ 2rr.I-2Ir.I3.

${ }^{27}$ Minn. Stat. (Henderson, I945) $\S$ I79.0r et seq:

${ }^{28}$ Mich. Stat. Ann. (Henderson, Supp. 1946) \& I7.454-I et seq.

${ }^{19}$ Colo. Stat. Ann. (Michie, Supp. 1946) c. $97, \$ 94(1)$ et seq.

${ }^{20} 29$ U.S.C.A. \& I57 (I947). ${ }^{2 r}$ Wis. Stat. (Brossard, I943) \& IIr.04.

2 Minn. Stat. (Henderson, I945) \& 179.15.

${ }^{23}$ Wis. Stat. (Brossard, I943) \& Irr.02(3).

${ }_{24}$ Colo. Stat. Ann. (Michie, Supp. 1946) c. 97, § 94(8)(4).

${ }_{25}$ Tbid., at $\$ 94(5)$ (3).

${ }^{26}$ This seems to have been the practice in Minnesota even though there is no express statutory authorization.

${ }_{27} \mathrm{~Pa}$. Stat. Ann. (Purdon, Supp. I946) tit. 43, \& 211.9(b).

${ }^{28}$ Wis. Stat. (Brossard, I943) $\S$ Irr.05(3). This seems also to be the effect of an amendment in Rhode Island. R.I. Acts (r942) c. I247, § 8(4).

${ }^{29}$ Statement before Senate Committee on Labor and Public Welfare, March 6, 1947. 
ployer has the same right as a union to petition the board for representation proceedings, which means that he can force an election where "a question concerning representation" is found to exist. The danger of permitting an unlimited employer right to petition for an election has always been that the employer might foreclose the possibility of successful organization by a premature petition filed before the union has had time fully to organize the plant or during a period of temporary dissatisfaction with the union, perhaps brought about by the calculated recalcitrance of the employer himself. Wisconsin ${ }^{30}$ and Colorado ${ }^{3 x}$ allow their boards no opportunity to exercise judgment and discretion in designating the unit appropriate for collective bargaining, but make the decision turn solely on the desires of the employees expressed by secret ballot.

As regards procedures, the state labor relations acts fall into three basic types. Under one type, which is patterned on the Wagner Act, administration of the statute is lodged in an administrative agency, to which is delegated the functions of investigation, prosecution, and adjudication. A safeguard is always contained against arbitrary action, however, since the agency must go into an appropriate state court to seek enforcement of its order unless voluntary compliance is obtained. Moreover, redress is purely remedial, never punitive. "The most conspicuous attributes of these administrative boards," Chairman Herzog of the NLRB has written, "are preliminary investigation by state employees [of charges filed], the encouragement of settlements between the parties consistent with the policies of the acts, the winnowing out of weak or frivolous cases which might otherwise be pressed to hearing by over-zealous private litigants, the elimination of protracted hearings wherever possible, and the evolution of a unified governmental policy on labor relations." ${ }^{32}$ Five states now utilize the administrative technique-Massachusetts, ${ }^{33}$ New York, ${ }^{34}$ Utah, ${ }^{35}$ Rhode Island ${ }^{36}$ and Connecticut. ${ }^{37}$

A second group of states-Pennsylvania, ${ }^{38} \mathrm{Wiscon} \sin ^{39}$ and Colorado ${ }^{40}$

${ }^{30}$ Wis. Stat. (Brossard, I943) $\&$ IIr.05(2).

3x Colo. Stat. Ann. (Michie; Supp. 1946) c. 97, § 94(5)(3).

32 Herzog, The Labor Relations Acts of the States, 224 Annals 19, 22 (1942).

33 Mass. Ann. Laws (I942) c. I50A, §§ 6, 7.

34 New York Labor Law (McKinney, I940) art. 20, § 706.

35 Utah Code Ann. (r943) § 42-I-r6(5).

${ }^{36}$ R.I. Gen. Laws (I94I) c. 1066, \&3(7).

37 Conn. Gen. Stat. (Supp. 1945) $\$ \$ 939$ h, $940 h$.

${ }^{38} \mathrm{~Pa}$. Stat. Ann. (Purdon, r940) tit. 43, \$2Ir.g.

39 Wis. Stat. (Brossard, I943) \& IIr.07.

${ }^{10}$ Colo. Stat. Ann. (Michie, Supp. 1946) c. 97, § 94(8)(I4). 
-utilize a quasijudicial technique. These state boards make no attempt to investigate charges or to effect voluntary settlements before a hearing which follows a charge as a matter of course. The theory is that the complaints are primarily matters of private rather than public concern. Hence, the burden of proving a charge is thrown upon the charging party rather than being undertaken by the board's legal staff. Since the right involved is considered to be a private one, the parties may withdraw the charges at will whether or not the purposes of the act are thereby served. The board's function is merely to act as the court of first resort. Under the Colorado statute an alternative procedure is provided, however, under which the commission can initiate complaints, but it is not clear whether the commission is empowered to, or will, engage in preliminary investigation or in prosecution. Redress in these three states is remedial, except that Colorado permits an additional or alternative punitive action.

The third group of states having labor relations acts-Michigan ${ }^{4 \mathrm{x}}$ and Minnesota ${ }^{42}$-utilize the established judicial system for the abatement of unfair labor practices. ${ }^{43}$ The state board is not authorized to take any action to prevent or remedy the commission of unfair labor practices designated in the statutes. Such action is placed wholly within the province of the courts, and for this reason these states have been said to utilize "the court technique." The commission of an unfair labor practice is made a misdemeanor under the Michigan statute 44 and, as in Colorado, ${ }^{45}$ made punishable by fine or imprisonment. Minnesota provides injunctive relief. ${ }^{46} \mathrm{It}$ should be noted that a discriminatorily-discharged employee in these states can invoke only the statutory penalty, whereas under the statutes utilizing the administrative or quasijudicial organization the employee can secure reinstatement with back pay. The result is that relatively little incentive has existed for prosecution. The regular law enforcement officer is nominally charged with prosecution under the statute. The action is brought in the appropriate court of general jurisdiction and the usual judicial procedure, including jury trial, is followed. While the preceding groups of states expedite cases in the courts arising under the state

4I Under a recent amendment to the Michigan statute the board is authorized to itself pursue legal or equitable remedies for any act in violation of the statute. Mich. Pub. Acts (1947) P.A. 318, \$ 22a.

42 Minn. Stat. (EIenderson, 1945) \$ 179.14.

43 This is of course the enforcement procedure provided in all of the states which have piecemeal labor legislation but do not have labor relations acts.

44 Mich. Stat. Ann. (Henderson, Supp. 1946) $\$ \S$ I7.454-ז5, x7.

45 Colo. Stat. Ann. (Michie, Supp. 1946) c. $97, \$ \$ 94(14),(23)$.

${ }_{46}^{6}$ Minn. Stat. (Henderson, r945) \& I79.I4. 
labor relation act, no priority is given to such litigation by Michigan or Minnesota. Under the administrative type of statute, remedies can be tailored to correct the violation. In states which utilize the court technique, however, remedy lies in damages secured in private civil actions or in criminal prosecution. Since there has been little incentive to secure either, it appears that there has, as a consequence, been little enforcement of these acts. ${ }^{47}$

Two types of jurisdictional clauses appear among the state labor relations acts. The first is the so-called restricted jurisdictional clause, embodied in the Pennsylvania act ${ }^{48}$ prior to 1943 , and the Massachusetts ${ }^{49}$ and Connecticut ${ }^{50}$ acts before 1947 , under which the state board's jurisdiction runs only to those cases not falling within the jurisdiction of the NLRB. In order to create concurrent jurisdiction over domestically housed interstate industries, however, all of these states now extend their acts beyond merely those employers engaged solely in intrastate commerce. These distinctions have, however, probably been rendered moot by the Supreme Court's decision in the Allegheny Ludlum case ${ }^{5 x}$ and the provisions of the Taft-Hartley Act, ${ }^{52}$ both of which narrowly confine the power of state boards. It was of course always true that even those state boards possessed of concurrent jurisdiction had to withdraw in the face of the NLRB, which had superior rights under the commerce and supremacy clauses of the Constitution. Until recently, however, state boards having concurrent jurisdiction acted when the NLRB did not. It is probably the law now that in those cases where the employer's operations affect interstate commerce a state board can act only where the NLRB cedes jurisdiction to it. And the national board is permitted to do this only where the policies of the two boards are consistent. Of course a state board operating under a restricted jurisdictional clause is by statute without jurisdiction over employers engaged in interstate commerce. Under a recent amendment to the Massachusetts act, the state board may not act, in the case of an employer subject to the NLRA, "unless the federal agency .... has declined to assert jurisdiction thereof, or except

47 This is the conclusion reached in an able study by Professor Killingsworth, The Labor Relations Acts of the States: A Study in Public Policy, being published by the University of Chicago Press.

${ }^{8}$ Pa. Stat. Ann. (Purdon, Supp. x946) tit. 43, § 2 rr.3(c).

49 Mass. Ann. Laws (1942) c. 150A, \& ro(b).

so Conn. Gen. Stat. (Supp. 1945) \& 933h(6).

5x Allegheny Ludlum Steel Corp. v. Kelley, 67 S.Ct. Io26 (r947); Bethlehem Steel Co. v. New York State Labor Relations Board, 67 S.Ct. 1026 (1947). These cases, which were decided together, are discussed in a note, infra.

$\$ 229$ U.S.C.A. $\$ 160($ a). 
where such federal agency has conceded to the commission jurisdiction over any such case or proceedings." 53 A similar amendmęnt was made in I947 to the Connecticut Labor Relations act. ${ }^{54}$

\section{THE REGULATION OF UNION METHODS}

With this reference to the adoption and amendment of the industrial relations acts, we turn now to consider the entire body of state labor relations legislation, including both piecemeal enactments and the comprehensive statutes, as they affect particular union methods. Legislation concerning union security provisions, coercion of non-union workers, picketing, boycotts, strikes, breach of contract and political action has been widespread. Such laws have been found in some states in statutes which regulate this or that aspect of labor activity. They have also been found in the labor relations acts, often added by subsequent amendment. At this point an attempt will be made to present a cross-section view of the state legislation adopted in the last decade regulating certain important union methods.

\section{UNION SECURITY PROVISIONS}

The Taft-Hartley Act specifically provides what has been the law in fact since I935: that where state law prohibits union security agreements, it shall control.5s

An unsympathetic source has defined union security as "organized labor's method of gaining the assistance of the employer in the task of providing and keeping employee support for the union." ${ }^{36} \mathrm{~A}$ spokesman for organized labor would probably define it as a method by which all employees who enjoy the benefits of unionism, in terms of higher pay and better working conditions, share the expense of maintaining the labor organization. In addition to this, he would probably call attention to the more harmonious relations between the workers, and would certainly emphasize the need of a check on employer discrimination.

Achievement of the closed shop has been a main objective of most strongly organized American local and international unions. This is in contrast with the situation today in England and Sweden where unionsecurity provisions are comparatively unknown, largely because of the general acceptance of unionism by management and the common practice of non-unionists to side with unionists in strike situations. As of 1946 , an estimated $7,400,000$ workers in the United States were covered by

${ }^{53}$ Mass. Acts (1947) c. $657, \$ \mathrm{ro}(\mathrm{b})$.

s4 Conn. Spec. L. (I947) P.A. I75, $\S 933$ h(6).

ss 29 U.S.C.A. § I64(b).

${ }^{6} 9$ N.A.M. Law Digest 32 (1946). 
closed- or union-shop agreements, and an additional 3,600,000 were covered by maintenance-of-membership provisions. ${ }^{57}$

The peak of the anti-closed shop legislative drive was reached in 1947 when twelve states passed statutes banning or limiting the use of some or all union security devices. This brought the total number of such states to eighteen. The bulk of these statutes fall into two easily 'distinguished groups. Those in the first group, of which there are fourteen in all, ${ }^{58}$ flatly proscribe all, or some, types of union-security agreements. The Georgia statute is typical. Its basic provision is that "No individual shall be required as a condition of employment, or of continuance of employment, to be or remain a member or an affliate of a labor organization. . . ." ${ }_{59}$ A number of these statutes also expressly provide that disciplinary expulsion from a union shall not be a basis for discharge, and this is probably implied where not expressed. Most either implicitly or expressly forbid, or declare to be against public policy and thus unenforceable, agreements between employers and labor organizations which make membership in a labor organization in any way a condition of employment. The statute in Maine prohibits closed-shop contracts but, however, permits the making of agreements for the union-shop. The New Hampshire law prohibiting a union-security agreement applies only to employers having five or fewer employees. Five states now have constitutional amendments banning all types of union security provisions, which generally provide "that the right to work shall not be denied or abridged because of membership or nonmembership in a labor union." "It should be noted that "right to work"

57 Extent of Collective Bargaining and Union Recognition, 1946, 64 Monthly Lab. Rev. $765,766-67$ (I946).

${ }^{58}$ Ariz. L. (I947) c. 8I (enforcement statute for I946 constitutional amendment); Ark. Acts (1947) c. IOI (enforcement statute for I944 constitutional amendment); Fla. Const. Declaration of Rights, amendment of $\S$ I2 (I944); Ga. L. (1947) No. $x_{4}$ o (operation specifically made retroactive); Iowa Acts (I947) C. 296; Me. L. (1947) C. 395, to appear as $₹ 4$ I-A of Me. Rev. Stat. (bans the closed shop but permits the union shop, thus extending the general provisions of the Taft-Hartley Act to Maine employers engaged in intrastate commerce); Neb. L. (1947) No. 344 (enforcement statute for Neb. Const. Art.r5, \$§ I3-r5); N.H. L. (1947) c. 194 (bans closed shop for employers of five or less employees); N.C. L. (r947) c. 328, I9 L.R.R.M. 3029 (operation said to be prospective only); N.D. L. (1947) c. 243 (operation suspended by filing of petition for referendum); S.D.L. (I945) C. 80 (enforcement statute of 1945 constitutional amendment); Tenn. Pub. Acts (I947) c. $3^{6}$ (operation stated to be prospective only); Tex. Ann. Rev. Civ. St. (Vernon, I947) art. 5207a (operation stated to be prospective only); Va. Acts (1947) c. 2 (operation stated to be prospective only). An Alabama statute seems to forbid union-security agreements, but the Alabama Supreme Court in a recent decision rejected this construction. Hotel \& Restaurant EmployeesInternational Alliance v. Greenwood, 3o So. 2d 696 (Ala., 1947 ).

59 Ga. L. (I947) No. $140, \S 2$.

${ }^{60}$ These states are Arkansas, Arizona, Florida, Nebraska and South Dakota. See note 58 supra. A constitutional amendment of this type has been proposed by the New Mexico legislature and will be voted on at the next general election. 
statutes and amendments are a double-edged sword: the employer can neither discriminate against an employee because he is or is not a member of a labor organization.

The sanctions erected against violation are somewhat diversified. Misdemeanor penalties are expressly provided for in the Arkansas, Georgia, Iowa, Nebraska, South Dakota and Tennessee statutes, varying from a minimum of a $\$ 500$ fine in Nebraska to a maximum of $\$ 1,000$ and twelve months on a chain gang in Georgia. In Arkansas any person, corporation or association making a contract in violation of the act may be fined not less than $\$ 100$ nor more than $\$ 5,000$ for each offense, and each day the unlawful contract is in effect is deemed a separate offense. Seven states permit imprisonment for violations. Arizona, Georgia and Iowa have given "the remedy of injunction .... to any individual whose employment is affected, or may be affected, by any [union-security] contract."6r Violators of these acts, who may be either unions or employers, are expressly made civilly liable to all persons damaged by the operation of the illegal agreement in Arizona, Georgia, North Carolina and Virginia. In North Carolina a union-security agreement is made "an illegal combination or conspiracy in restraint of trade," ${ }^{2}$ and in Virginia "an illegal combination or conspiracy." ${ }_{3}$ These classifications in those two states carry with them all three sanctions-civil and criminal liability, and injunction. ${ }^{64}$

A second type of statute, while not proscribing all union security provisions, permits such agreements only where they have been validated by a referendum among the employees concerned. Wisconsin pioneered in such a procedure in $1939 .{ }^{65}$ Between that time and the adoption of the Taft-Hartley Act, which includes such a provision, ${ }^{66} \mathrm{Colorado}_{,}{ }^{67} \mathrm{Kansas}^{68}$ and New Hampshire ${ }^{69}$ enacted statutes stemming from the same basic theory. The core of the Wisconsin-type statute is the requirement of a referendum to determine whether a specified proportion of the employees in the unit wish to give their elected bargaining agent authority to negoti-

${ }^{6 x} \mathrm{Ga}$. L. (1947) No. I40, $\$ 8$.

${ }^{62}$ N.C. L. (1947) c. $328, \S 2$.

${ }^{6}$ Va. Acts (1947) c. $2, \S 2$.

${ }^{6} 4$ N.C. Gen. Stat. (Michie, 1943) $\S \S 75^{-1}, 75^{-14}$ through 75-16; Va. Code Ann. (Michie, I942) $\$ \$ 4722(9)$, (rx) and (I4).

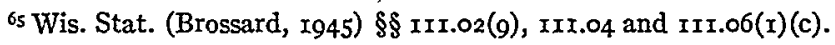

6629 U.S.C.A. \& $158(\mathrm{a})(3)(1947)$.

${ }^{67}$ Colo. Stat. Ann. (Michie, Supp. 1946) c. $97, \S \S 94(\mathrm{I})(4), 94(2)(7), 94(6)(\mathrm{c}), 94(7)(\mathrm{r})$ 94(I6) and 94(I7).

${ }^{68} \mathrm{Kan}$. Gen. Stat. (Corrick, Supp. 1945) \& 44.803, 44.809(4) and (5).

${ }^{69}$ N.H. L. (1947) C. 194, amendment of N.H. Rev. Laws (1942) c. 212, § 21. 
ate a union-security agreement with the employer..$^{70}$ Of course, the mere authorization of such an agreement in an employee referendum is but a preliminary step in the attainment of a union shop; it must still be voluntarily granted by the employer at the bargaining table. Under the terms of the I939 Wisconsin statute, the union security agreement had to be authorized by a vote of three-fourths of all the employees. In I945 the required majority was reduced to two-thirds of those voting, subject, however, to a I943 amendment which required that this constitute a majority of all the employees..$^{75}$ The 1943 amendment also provided for a new referendum at the request of either party to the agreement, subject to a finding by the board that "there is reasonable ground to believe that there exists a change in the attitude of the employees concerned toward the allunion agreement. . ..." $7^{2}$ If the referendum does not result in the necessary majority, the union-security provision is considered terminated at the expiration of the contract of which it is then a part or at the end of one year from the date of the announcement by the board of the result of the referendum, whichever proves to be the earlier date. Another important provision of the Wisconsin statute requires the state board to declare any union-security agreement terminated where it finds "that the labor organization involved has unreasonably refused to receive as a member any employee of such employer." 73

The Colorado statute, passed in I943, is similar to the I939 Wisconsin statute. Thus, it requires a three-fourths vote to authorize a union-security agreement ${ }^{74}$ and provides no machinery for reopening the question. The application of the proviso has not, however, been extended to maintenance-of-membership provisions as in Wisconsin. The Kansas statute requires merely a majority vote to authorize an all-union agreement. ${ }^{75}$ Both the Colorado and Kansas statutes forbid undemocratic membership policies by unions..$^{66}$ The New Hampshire statute combines both types of union security legislation. It absolutely forbids such agreements in the case of employers having five or fewer employees. ${ }^{77}$ Such an agreement can be entered into by an employer of more than five employees if sup-

\footnotetext{
7o This goes beyond the requirements of the original National Labor Relations Act's unionsecurity restrictions. It simply required that the bargaining union not be employer-dominated and that it be the free choice of a majority of the employees in the unit. 49 Stat. 452 (1935), 29 U.S.C.A. $\$ \$ 158(2)$ and (3) (1947).

72 Wis. Stat. (Brossard, I943) \& III.06(I)(c). $\quad 72$ Tbid. 73 Ibid.

${ }^{74}$ Colo. Stat. Ann. (Michie, I946) c. $97, \S 94(6)$ (c).

${ }^{75} \mathrm{Kan}$. Gen. Stat. (Corrick, Supp. I945) $\$ \S 44.803,44.809(4)$ and (5).

${ }^{76}$ Colo. Stat. Ann. (Michie, r946) c. $97, \S 94(\mathrm{r})(4)$; Kan. Gen. Stat. (Corrick, Supp. I945)
} $\S 44.801$.

7 N.H. L. (1947) c. I94, § 21. 
ported by a two-thirds majority of the employees voting, where it is also a majority of all the employees. Union-security contracts are required to include clauses providing that the labor organization shall practice no arbitrary discrimination in its membership policy and give members suspended or expelled a right of appeal through organization channels to the state labor commissioner, whose decision is binding on the union..$^{8} \mathrm{~A}$ recent amendment to the Massachusetts Labor Relations Act forbids an employer to discharge or otherwise discriminate against an employee for nonmembership in a labor union having a closed-shop agreement with the employer, unless the union certifies that the employee was deprived of membership because of a bona fide occupational disqualification or in the administration of discipline. ${ }^{79}$ The act sets up a procedure by which the labor relations commission can determine whether an employee has been unlawfully suspended or expelled or refused membership in the union. ${ }^{80}$ The Delaware law exempts controversies over union security provisions from its definition of a labor dispute. ${ }^{8 x}$

\section{THE CHECK-OFF}

The check-off is an arrangement whereby the employer deducts union dues or assessments from the employees' earnings and delivers the sum total to the union. The check-off may be automatic, requiring the deduction to be made regardless of the wishes of the individual employee, or it may be voluntary, permitting such deduction only upon an authorization by the individual employee. It was estimated that $6,000,000$ workers were covered by check-off provisions in I 946 , of which slightly more than half provided for the automatic type. ${ }^{82}$ Three states-Colorado, ${ }^{83}$ Pennsylvania $^{84}$ and Wisconsin ${ }^{85}$ - have outlawed the automatic or compulsory check-off by declaring it to be an employer unfair labor practice. These same states, however, legalize the voluntary check-off where the employer obtains a written order therefor signed by the employee. Similar provi-

$7^{8}$ Ibid., at $\S 2 \mathrm{I}-\mathrm{aIII}-\mathrm{IV}$.

${ }^{79}$ Mass. Acts (1947) c. 657, added as $\$ 6 A$ to c. I50A of Mass. Ann. Laws.

${ }^{80}$ Ibid.

$8 x$ Del. L. (I947) c. $196, \S \mathrm{I}(1)(3)$.

${ }_{22}$ Extent of Collective Bargaining and Union Recognition, I946, 64 Monthly Lab. Rev. 765,768 (1946).

${ }^{83}$ Colo. Stat. Ann. (Michie, Supp. 1946) c. 97, $\$ 94(6)(\mathrm{I})(\mathrm{i})$.

84 Pa. Stat. Ann. (Purdon, 194x) tit. 43, $\$ 211.6(\mathrm{r})(\mathrm{b})$.

85 Wis. Stat. (Brossard, 1943) § IIr.06(r)(i). 
sions also exist in Georgia, ${ }^{86}$ Arkansas, ${ }^{87}$ Delaware, ${ }^{88}$ Rhode Island ${ }^{89}$ and Texas. ${ }^{90}$. The check-off is permitted in Iowa only on the written request of the employee, countersigned by the spouse, and is revocable on thirty days' notice, ${ }^{91}$ while in Georgia it is revocable at will. ${ }^{92}$ Pennsylvania requires approval by majority vote of the employees in the bargaining unit before even the voluntary check-off is permissible. ${ }^{93}$

\section{WORK PERMITS}

Under the work permit fee system non-union men pay a stipulated sum to the union for the privilege of working on a closed-shop job when the union is unable to provide all the men needed. Those eleven states outlawing the closed shop have thereby obviated the raison d'être of the work permit system. Selling work permit cards has specifically been made illegal in Alabama, ${ }^{94}$ Delaware, ${ }^{95}$ Iowa, ${ }^{96}$ Massachusetts, ${ }^{97}$ New York ${ }^{98}$ and Texas. ${ }^{99}$ Iowa, ${ }^{\text {100 }}$ New Hampshire, ${ }^{\text {,0x }}$ North Carolina, ${ }^{\text {102 }}$ Tennessee ${ }^{\mathrm{x} 03}$ and Virginia ${ }^{104}$ make it unlawful to require any person to pay a fee or assessment to a union as a condition of employment.

\section{COERCIVE TACTICS}

Though by no means general, the history of the American labor movement has been replete with violence on the industrial scene. Such tactics by unions have, however, always been subject to the criminal law. There has been no love lost between the union worker and his non-union colleague - endearingly known in the trade as a "scab"-and the latter has

${ }^{86}$ Ga. L. (I947) No. 140, \$6, I9 L.R.R.M. 3052.

${ }^{87}$ Ark. Acts (1947) c. 101, I9 L.R.R.M. 3029.

${ }^{88}$ Del. L. (1947) C. $196, \S_{4}$ (b), 19 L.R.R.M. 3055. Only "a court of competent jurisdiction" can authorize a check-off under this section.

${ }^{89}$ See Acee, State Labor Legislation in 1947, 65 Monthly Lab. Rev. I, 7 (1947).

90 Tex. L. (1947) H.B. 22, 20 L.R.R.M. 3023.

9x Iowa Acts (1947) S.B. I09, \& 5, 20 L.R.R.M. 3007.

92 Ga. L. (I947) No. I40, 8 6, I9 L.R.R.M. 3052.

93 Pa. Stat. Ann. (Purdon, I94r) tit. 43, $\$ 2$ r.6(r)(b).

94 Ala. Gen. Acts (1943) 257, § 15 .

95 Del. L. (1947) c. 196, $\$ 20$, 19 L.R.R.M. 3058.

${ }^{96}$ Iowa Acts (1947) S.B. I09, § 4, 20 L.R.R.M. 3007.

${ }_{77}$ Mass. Ann. Laws (Supp. 1946), c. I49, 8 I50b.

${ }^{8}$ See People v. Fay, 882 N.Y. Misc. 358, 43 N.Y.S. $2 d 826$ (1943).

99 Tex. Ann. Rev. Civ. Stat. (Vernon, Supp. x946) tit. 83 , art. 5 154a, $\$ 8 \mathrm{a}$.

${ }^{200}$ Iowa Acts (1947) c. $296, \$ 4$.

${ }^{301}$ N.H. L. (1947) C. 194, \& 21.

${ }^{\text {ro3 }}$ Tenn. Pub. Acts (I947) S.B. $3^{67}, \S 3$.

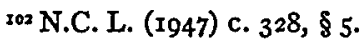

${ }^{204}$ Va. L. (I947) c. $2, \S 5$. 
in recent years been singled out for special legislative protection. The forerunner of much of this legislation was a Washington law of Igog which declared it to be a gross misdemeanor for two or more persons "to pre, vent another from exercising any lawful trade or calling, or from doing any lawful act, by force, threats or intimidation or by interfering or threatening to interfere with any tools, implements or property belonging to or used by another, or with the use of [or] employment thereof." states now by statute have specifically prohibited the intimidation of nonunion workers. ${ }^{\mathrm{ro6}} \mathrm{Ten}$ states, principally in the South and Southwest, have enacted anti-violence statutes. ${ }^{107}$ Six states achieve a similar result by prohibiting such conduct as an employee unfair labor practice. ${ }^{\mathrm{x} 08}$ An indication of the degree of protection which some state legislatures have sought to give to non-union workers can be had from a glance at the following Nebraska statute:

It is unlawful for any person or persons, singly or by conspiring together, to interfere, or attempt to interfere with another person in the exercise of his or her lawful right to work, or to enter upon or pursue any lawful employment he or she may desire by doing any of the following acts: I) using profane, insulting, indecent, offensive, annoying, abusive or threatening language toward such person or any member of his or her immediate family, or in his, her or their presence, or hearing for the purpose of inducing or influencing, or attempting to induce or influence, such person to quit his or her employment, or to refrain from seeking or freely entering into employment, or by persisting in talking to or communicating in any manner with such person or members of his or her immediate family against his, her or their will, for such purpose; 2) following or intercepting such person from or to his work, from or to his home or lodging, or about the city, against the will of such person, for such purpose; 3) photographing such person against his will; 4) menacing, threatening, coercing, intimidating or frightening in any manner, such person for such purpóse; 5) committing an assault or assault and battery upon such person for such purpose; or 6) loitering about, picketing or patroling the place of work or residence of such person, or any street, alley, road, highway, or any other place, where such person may be, or in the vicinity thereof, for such purpose, against the will of such person. ${ }^{109}$

ro5 Wash. Rev. Stat. Ann. (Remington, 1932) \& 2382(5).

${ }^{106}$ Ala., Ark., Colo., Del., Fla., Ga., Kan., Mich., Minn., Miss., Neb., Pa., Tex., Utah, Va., and Wis.

${ }^{107}$ Ala. Gen. Acts (1943) 256, § 9; Ark. Stat. Ann. (Pope, Supp. 1944) Part II, Crim. L. 7, $\S \S$ I-2; Del. L. (x947) c. I96, §§ 2(a), 4(a); Fla. Gen. L. (x943) c. 2xg68, §9(I)(g), (II); Ga. L. (I947) No. x4I, §§ I, 6; La. Gen. Stat. Ann. (Dart., Supp. I947) §4379.22(a); Mich. Pub. Acts (I947) No. 297, C. 5I, § 352, 20 L.R.R.M. 3097; Neb. Rev. Stat. (I943) § 28-81 2; Miss. Code Ann. (1942) \& 2126; Tex. Ann. Pen. Code (Vernon, Supp. 1946) art. I62Ib, § I, Va. Code Ann. (Michie, Supp. I946) § 47IIa.

${ }^{108}$ Colo. Stat. Ann. (Michie, Supp. 1946) c. 97, $\$ 94(6)$ (2) (a), (b), (f); Kan. L. (I943) c. rgr, § 8(I4); Minn. Stat. (Henderson, I945) § I79.II(7); Pa. Stat. Ann. (Purdon, I94I) tit. 43, § 2rr.6(2)(a); Utah L. (1947) H.B. 36, § 49-I-I6(2)(a); Wis. Stat. (Brossard, 1943) $\S 111.06(2)(\mathrm{a})$.

${ }^{309}$ Neb. Rev. Stat. (1943) \& 28-8I 2. 
An amendment to the Pennsylvania act makes it an unfair labor practice for an employee or a labor organization to intimidate, restrain or coerce any employee for the purpose of compelling him to join or refrain from joining any labor organization, or for the purpose of influencing his selection of representatives for collective bargaining. ${ }^{\text {Iro }}$ Previously such action was an unfair labor practice only if accompanied by threats of force or violence.

\section{PICKETING AND RELATED STRIKE ACTIVITY}

Even though the Thornhill doctrine was itself enunciated in a sweeping decision holding unconstitutional an Alabama anti-picketing statute, on the theory that picketing is a form of freedom of speech, the states have continued in attempts to regulate various aspects of picketing.

Five states permit picketing only if a majority of the employees have voted in favor of a strike. ${ }^{\text {II }}$ Thus, Wisconsin in I939 declared it to be an unfair labor practice for any person "to cooperate in engaging in, promoting or inducing picketing, boycotting or any other overt concomitant of a strike unless a majority in a collective bargaining unit of the employees of an employer against whom such acts are primarily directed have voted by secret ballot to call a strike." ${ }^{122}$ In 1943 , Wisconsin, in an obvious bow to the Supreme Court, inserted the following after the word "picketing" in the above sentence: "(not constituting an exercise of constitutionally guaranteed free speech)." Picketing is prohibited in Missouri and South Dakota in the absence of a labor dispute between the employer and his employees. ${ }^{\mathrm{x} 3}$ South Dakota by statute prohibits picketing accompanied by force or violence ${ }^{\mathrm{Ir} 4}$-as have many states and municipalities for decades.

Mass picketing has been specifically prohibited by legislation in thirteen states. A I946 Virginia statute declares unlawful "picketing by force or violence, or to picket alone or in concert with others in such manner as to obstruct or interfere with free ingress and egress to and from any premises." ${ }^{125} \mathrm{~A}$ similar result is achieved by provisions in Colorado, ${ }^{\mathrm{xr} 6}$

${ }^{120}$ Pa. L. (1947) No. 558, §6(2)(a).

"Ir Colo. Stat. Ann. (Michie, Supp. 1946) c. 97, $\$ 94(6)$ (2)(e); Del. L. (1947) c. 196, § 2(e); N.D. L. (I947) H.B. 160, $\$$ I2 (subject to referendum); Utah L. (1947) H.B. $36, \S 49-1-16$ (2)(c); Wis. Stat. (Brossard, I943) \& III.06(2)(e).

$1 \times 2$ Wis. Stat. (Brossard, I943) § IIr.06(2)(e).

${ }_{113}$ Mo. L. (1947) S.B. 79, \& 8; S.D. L. (1947) c. 93, 2A C.C.H. Lab. L. Serv. 46,402-3.

${ }^{2 \times}$ S.D. L. (1947) c. 93, 2A C.C.H. Lab. L. Serv. 46, 402-3.

rxs Va. Code Ann. (Michie, Supp. 1946) $\$ 47$ Ira.

${ }^{126}$ Colo. Stat. Ann. (Michie, Supp. 1944) c. $97, \S 94(6)(2)(\mathfrak{f})$. 


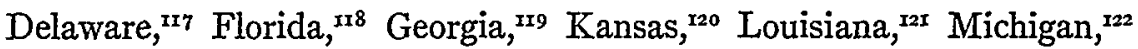
Minnesota, ${ }^{\mathrm{I} 23}$ South Dakota, ${ }^{\mathrm{I} 24}$ Texas, $^{\mathrm{1} 25} \mathrm{Utah}^{\mathrm{12} 6}$ and Wisconsin. ${ }^{\mathrm{I27}}$ But what is mass picketing? The South Dakota statute defines it as "picketing by a greater number than five per cent of the first one hundred striking or locked out employees of the picketed employer and one per cent of the employees in excess of this number. ...." ${ }^{\prime 28}$ In Texas, mass picketing means any form of picketing in which there are more than two pickets at one time within 50 feet of any entrance to the premises being picketed. ${ }^{129}$ Minnesota has also limited the number of pickets, by making it an unfair labor practice "for more than one person to picket or cause to be picketed a single entrance to any place of employment where no strike is in progress at the time." ${ }^{130}$

Stranger picketing has been the object of frequent legislative attack. A I947 South Dakota statute declares that "it shall be unlawful for any person not a bona fide employee of the picketed employer to act as a picket." ${ }^{3^{3} \mathrm{x}}$ Pennsylvania ${ }^{\mathrm{r} 32}$ and Virginia ${ }^{\mathrm{r33}}$ have similar statutes. Minnesota permits stranger picketing during a strike only where "the majority of persons engaged in picketing the place of employment at these times are employees of the place of employment." ${ }^{34}$ Stranger picketing, where no labor dispute exists between the immediate employer and his employees and where the employees have not voted to strike, has been held to be an unfair labor practice in Wisconsin, ${ }^{135}$ and would presumably be the same under identically-worded provisions in the Colorado ${ }^{136}$ and $\mathrm{Utah}^{\mathrm{137}}$ acts.

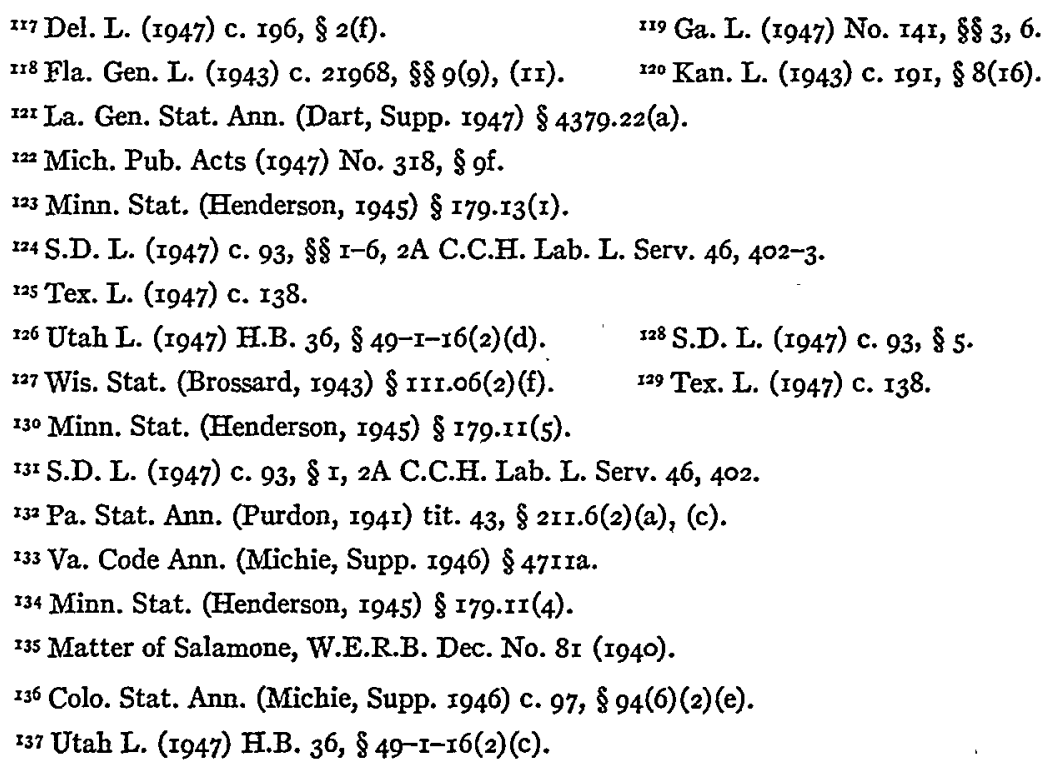


An Oregon statute ${ }^{\mathrm{r}_{3} 8}$ prohibiting stranger picketing, it may also be noted, was held to be unconstitutional. ${ }^{139}$

A few states protect a special class from the inconvenience of picketing, as in Idaho, ${ }^{\mathrm{I} 4^{\circ}}$ South Dakota ${ }^{\mathrm{I}{ }^{\mathrm{I}}}$ and Minnesota ${ }^{\mathrm{x}{ }^{\mathrm{I}}}$ which have granted special protection to agricultural premises. The Idaho statute provided that "No person shall picket upon any ranch, farm, feed yard, shearing plant, processing plant or other agricultural premises. . . .." ${ }^{43}$

The picketing of a worker's home has been banned in eight states. Five states-Colorado, ${ }^{\mathrm{X} 44}$ Delaware, ${ }^{\mathrm{X} 45} \mathrm{Utah}^{\mathrm{x} 46}$ and Wisconsin ${ }^{\mathrm{I} 47}$-outlaw such picketing as an unfair labor practice. A Kansas statute makes it illegal to intimidate a worker's family, "picket his domicile or injure the person or property of such employee or his family." ${ }^{148}$ Connecticut, ${ }^{149}$ Michigan $^{150}$ and Nebraska ${ }^{15 x}$ also have enacted comparable statutes.

Minnesota in I945 prohibited picketing, strikes or boycotts designed to upset a valid certification, subjecting the obstreperous union to a suit for damages..$^{x^{2}}$ This is the type of situation in which a minority union seeks to force the employer to recognize it as collective bargaining representative for the employees in a unit for which another union has been certified as the bargaining agent. Another approach to the same problem is found in statutes in Pennsylvania ${ }^{153}$ and Delaware ${ }^{\mathrm{T54}}$ which in effect authorize injunctions to issue under such circumstances. Still a third solution to the problem is available in Wisconsin, ${ }^{\mathrm{x} 5}$ Colorado $^{\mathrm{x56}}$ and Delaware ${ }^{\mathrm{x57}}$ which make such conduct an unfair labor practice.

${ }_{338}$ Ore. Comp. Laws Ann. (I940) \& I02-908.

${ }^{139}$ AFL v. Bain, 165 Ore. 183 , x06 P. 2d 544 (1940); cf. AFL v. Swing, 3 I2 U.S. 321 (1940). ${ }^{x_{40}}$ Idaho L. (I943) C. $76, \$ 83,4$. Held unconstitutional in AFL v. Langley, I68 P. $2 d 83 \mathrm{I}$ (Idaho, I946).

${ }^{14 x}$ S.D. L. (1943) c. 86, $\$ 3$. Held unconstitutional in part in AFL v. Mickelson, 9 C.C.H. Lab. Cas. 67,064 (S.D. Cir. Ct., 1944).

${ }^{4} 4_{2}$ Minn. Stat. (Henderson, I945) \& I 79. I I (9).

${ }^{43}$ Idaho L. (1943) c. $76, \$ \S 3,4$.

${ }^{244}$ Colo. Stat. Ann. (Michie, Supp. I946) c. $97, \$ 94(6)(2)(a)$.

${ }_{445}$ Del. L. (1947) c. I96, § 2 a.

${ }_{14} 6$ Utah L. (1947) H.B. $36, \S 49-I-16(2)$ (a).

r47 Wis. Stat. (Brossard, I943) $\S$ Irr.o6(2)(a).

${ }_{248}^{8} \mathrm{Kan}$. L. (1943) c. I9I \$ 8(14).

${ }^{149}$ Conn. Spec. L. (1947) No. I23, 20 L.R.R.M. 3059.

${ }^{150}$ Mich. Pub. Acts (1947) No. 318, § gf. . $\quad{ }^{15 x}$ Neb. Rev. Stat. (1943) § 28-8I2.

${ }_{152}$ Minn. Stat. (Henderson, I945) \& 179.27 .

${ }^{253} \mathrm{~Pa}$. Stat. Ann. (Purdon, I94I) tit. 43, § 206d. $\quad{ }_{154}$ Del. L. (r947) c. I96, § I(l)(4).

sss Wis. Stat. (Brossard, I943) \& $\operatorname{mr} 1.06(2)(d)$.

${ }^{256}$ Col. Stat. Ann. (Michie, Supp. 1944) c. $97, \$ 94(6)(2)(d)$.

${ }^{257}$ Del. L. (I947) C. 196, \& 2(d). 
It seems apparent that when the Supreme Court passes upon much of the state anti-picketing legislation discussed in this section it will be invalidated unless the Court decides to abandon entirely the much-battered Thornhill doctrine.

\section{BOYCOTIS}

Secondary boycotts have been subjected to rigorous legislative attack in fourteen states-Alabama, ${ }^{158}$ California, ${ }^{\text {I59 }}$ Colorado, ${ }^{160}$ Delaware, ${ }^{16 x}$ Idaho, ${ }^{162}$ Iowa, ${ }^{163}$ Minnesota, ${ }^{164}$ Missouri, ${ }^{165}$ North Dakota, ${ }^{166}$ Oregon, ${ }^{167}$ Pennsylvania, ${ }^{168}$ Texas, $^{169} \mathrm{Utah}^{170}$ and Wisconsin. ${ }^{175}$ The majority-the so-called "hot cargo" statutes-prohibit the refusal by persons not directly concerned in the labor dispute to handle or work on non-union-made materials or supplies. A few statutes are more comprehensive, proscribing all secondary boycotts, which was the general rule at common law. The I947 Minnesota statute outlawed any secondary boycott as "an illegal combination in restraint of trade and in violation of the public policy of this state." ${ }^{172}$ Earlier, Minnesota, ${ }^{173}$ as well as Idaho, ${ }^{174}$ South Dakota ${ }^{175}$ and Oregon, ${ }^{176}$ had legislated to protect agriculture from interference through the secondary boycott. Such protection was made ambulatory, extending to the protection of food even during processing and marketing. The latter three statutes were, however, subsequently held to be unconstitutional, as were the "hot cargo" acts in Alabama and California..77 Under the North Dakota law, secondary boycotts and sympathy strikes

${ }^{258} \mathrm{Ala}$. Gen. Acts (1943) 256, $\S$ I2. Invalidated in AFL v. McAdory, 246 Ala. I, 18 So. 2d 8 Io (I944).

${ }^{159}$ Cal. Stat. (1947) c. 278. Invalidated in Ex parte Blaney, 184 P. 2d 892 (Cal., I947).

${ }^{260}$ Colo. Stat. Ann. (Michie, Supp. x946) c. $97, \S 94(6)(2)(\mathrm{g})$.

I6x Del. L. (x947) c. I96, $\S 2(\mathrm{~g}), 6$.

${ }^{262}$ Idaho L. (I947) c. 265 , I9 L.R.R.M. 3050.

${ }^{363}$ Iowa Acts (1947) C. 297, § I, 20 L.R.R.M. 301 2.

${ }^{26} 4 \mathrm{Minn}$. L. (x947) C. 486, §4, 20 L.R.R.M. 3012.

${ }^{165}$ Mo. L. (I947) S.B. 79, § 8, 20 L.R.R.M. 3093.

${ }_{166}$ N.D. L. (I947) H.B. $160, \S \mathrm{I} 3$.

${ }^{167}$ Ore. L. (I947) C. 356,20 L.R.R.M. 3003 .

${ }^{169}$ Tex. L. (1947) c. ${ }_{387}, 20$ L.R.R.M. 3090 .

${ }^{168}$ Pa. L. (r947) No. 558, $\$ 6(2)(d)$.

$1_{70}$ Utah L. (I947) c. 66, $\$ 49-\mathrm{I}-\mathrm{I6}(2)(\mathrm{e})$.

${ }^{17 x}$ Wis. Stat. (Brossard, x943) § III.06(2) (g). $\quad{ }^{172}$ Minn. L. (r947) c. $486, \S 4$.

${ }_{733}$ Minn. Stat. (Henderson, I945) § I 79.Ir(9).

${ }^{774}$ Idaho L. (I943) c. $76, \S \S 3$, 4. Invalidated in AFL v. Langley, 66 Idaho $76_{3}$, x68 P. 2d 83 I (I946).

${ }^{175}$ S.D. L. (1943) c. $86, \S 3$.

${ }^{176}$ Ore. Comp. Laws Ann. (I940) $\S$ 102-907. Invalidated in AFL v. Bain, I65 Ore. 183, ro6 P. 2d 544 (1940).

${ }_{177}$ See cases cited notes $x_{4} \mathrm{r}, \mathrm{r}_{5} 8, \mathrm{I}_{59}, \mathrm{r}_{74}$ and ${ }_{776}$, supra. 
are declared to be against public policy and illegal..$^{78}$ They are made subject to injunctive relief as well as suits for damages. In Massachusetts boycotts are unlawful when used to force the commission of an unfair labor practice..$^{79}$

\section{STRIKES}

Even though it has been generally assumed since the Wolff case $^{\mathrm{r80}}$ that the right to strike cannot be entirely banned, a number of states have enacted legislation limiting the right in certain respects.

Some states have set up certain procedural requirements which the union must meet prior to a strike. Eleven states have passed laws making strikes illegal unless approved by a majority vote prior to the walkout. They are Alabama, ${ }^{181}$ Colorado, ${ }^{182}$ Delaware, ${ }^{183}$ Florida, ${ }^{184}$ Kansas, ${ }^{185}$ Louisiana, ${ }^{186}$ Minnesota, ${ }^{187}$ Missouri, ${ }^{188}$ North Dakota, ${ }^{189}$ Oregon, ${ }^{190}$ $\mathrm{Utah}^{\mathrm{x} 9 \mathrm{x}}$ and Wisconsin. ${ }^{\mathrm{x} 2}$ The Florida statute provides that it shall be unlawful for any person "to participate in any strike, walk-out, or cessation of work or continuation thereof without the same being authorized by a majority vote of the employees to be governed thereby; provided, that this shall not prohibit any person from terminating his employment of his own volition." ${ }^{193}$ The purposes of such legislation are said to be, first, to provide some assurance to the employer and the majority of the employees in the bargaining unit that their working agreement will not be disrupted by a dissident minority; second, to assure both to the employer and to the employees that strikes will not be called by irresponsible labor leaders without consulting the membership; and, third, possibly to delay the calling of a strike so as to afford additional time for settlement of the dis-

178 N.D.L. (1947) c. $242,8 \mathrm{r}$.

179 Mass. Acts (1947) c. I5OA, $\$ 4 \mathrm{~A}(2)(\mathrm{a})$.

${ }^{180}$ Wolff Packing Co. v. Kansas, 262 U.S. 522 (1923), 267 U.S. $55^{2}$ (1925).

${ }^{88}$ Ala. Gen. Acts (1943) 257, \& 13.

${ }^{182}$ Colo. Stat. Ann. (Michie, Supp. I946) c. 97, $\S 94(6)(2)(e)$.

${ }_{183}$ Del. L. (I947) C. I96, \& 2(e)

${ }^{284}$ Fla. Gen. L. (1943) C. 21968, $\$ 9(3)$.

${ }^{185} \mathrm{Kan}$. L. (1943) c. 19I, § 8(3).

${ }^{186} \mathrm{La}$. Acts (I946) Act No. $180, \S_{3}$ (b). The statute merely provides that a strike must be authorized by the labor organization. It is not clear whether the union leadership can authorize a strike in the absence of a vote.

${ }^{287}$ Minn. Stat. (Henderson, I945) \& $\times 79.11(8)$.

${ }^{88}$ Mo. L. (1947) S.B. 79, §3.

${ }^{889}$ N.D. L. (1947) C. $242, \S$ II.

r90 Ore. Comp. Laws Ann. (r940) $\$$ 102-906. Invalidated in AFL v. Bain, 3x Ore. 87, 106

P. $2 d 544$ (I940).

rgx Utah L. (1947) C. 66, $\$ 49-\mathrm{I}-\mathrm{I} 6(2)$ (c).

${ }^{190}$ Wis. Stat. (Brossard, 1943) \& IrI.06(2)(e).

293 Fla. Gen. L. (1943) c. 21968, \$9(3). 
pute or to enable the employer to be better able to withstand the disruption when it occurs.

One of the frequent devices used to avert strikes has been the coolingoff period (which in operation could perhaps be more aptly termed a heating-up period). Prior to the 1947 legislative sessions, six states required such a period under certain circumstances before a strike could legally take place. ${ }^{194}$ This was sometimes done in the hopes that a settlement could be effectuated in the interim, but when, for example, Wisconsin passed a statute which required a ten-day notice to strike in agricultural industries, ${ }^{195}$ the purpose seems clearly to have been to prevent a union coup d'état which could result from the perishable nature of the commodities involved. Colorado requires a twenty-day strike notice in all except agricultural industries, where ten additional days are required..$^{\mathrm{x} 96} \mathrm{~A}$ few states simply require notification to the employer or state department of labor that a strike is impending. Violations are generally made misdemeanors, punishable by fine or imprisonment.

The attention of the 1947 legislators was directed to the problem of strikes in essential industries because of the great shut-downs which followed the coal strike of $x 946$. As a result special legislation was enacted in ten states to regulate industrial disputes between public utilities and their employees. ${ }^{197}$ All of these laws contain restrictions on strikes and provide severe penalties for violations. The laws of Florida, ${ }^{x 98}$ Indiana, ${ }^{199}$ Michigan, ${ }^{200}$ Nebraska, ${ }^{201}$ New Jersey, ${ }^{202}$ Pennsylvania ${ }^{203}$ and Wisconsin ${ }^{204}$ establish machinery for compulsory arbitration. In Florida, for example, after an impasse is reached in collective bargaining between a public utility and its employees, either party can petition the governor, who may appoint a conciliator to attempt settlement of the dispute. The conciliator has 45 days in which to effect a settlement. During this period neither a strike nor a lockout is permissible. At the end of this period if no settlement has been

${ }_{94}$ Colo. Stat. Ann. (Michie, Supp. 1946) c. $97, \S 94(\mathrm{II})(2)$; Ga. L. (x94I) No. 293, §§ 3, 4; Ky. Rev. Stat. (Cullen, I946) $\$ 336$. I50; Mich. Stat. Ann. (Henderson, Supp. I946) \& 17.454-9; Minn. Stat. (Henderson, I945) \& I79.06; Wis. Stat. (Brossard, I943) \& III.II(2).

195 Wis. Stat. (Brossard, I943) § IIr.rx(2).

${ }^{186}$ Colo. Stat. Ann. (Michie, Supp. 1946) c. 97, §94(II)(2).

197 Fla., Ind., Mass., Mich., Mo., Neb., N.J., Pa., Tex., Va., and Wis.

198 Fla. Gen. L. (I947) c. $23911 ; 2$ A C.C.H. Lab. L. Serv. 42,I0I-2.

199 Ind. Acts (r947) c. $34 \mathrm{I}$.

${ }^{200}$ Mich. Pub. Acts (1947) No. 3 I8.

${ }^{20 x}$ Neb. L. (1947) L.B. 537

${ }^{202}$ N.J. Acts (1946) c. 38 , as amended by cc. 47 and 75 of N.J. Acts (I947).

${ }^{203}$ Pa. Stat. Ann. (Purdon, Supp. I947) tit. 2I3, $\$ 8$.

${ }^{204}$ Wis. L. (I947) C. 4 I4, $\$$ III. 55 . 
reached, and if "the Governor believes that a continuation of the dispute will cause or is likely to cause the interruption of the supply of a service on which the affected community is so dependent that severe hardship would be inflicted on a substantial number of persons by a cessation of service, he shall appoint a Board of Arbitration to hear and determine such dispute." 205

In Missouri, ${ }^{206}$ Massachusetts, ${ }^{207}$ New Jersey ${ }^{208}$ and Virginia, ${ }^{209}$ the governor is authorized to take over and operate the plant or facility if the parties cannot effect a settlement. These same four states prohibit strikes, and Nebraska bans both strikes and lock-outs after a public utility has been taken over by the state. ${ }^{200}$ It is also generally provided that no strike or lock-out shall take place during mediation or arbitration proceedings. Picketing of the premises of a public utility is unlawful in Texas and may be enjoined. ${ }^{2 x}$ The Virginia act specifically prohibits picketing after the governor has taken possession of a utility. ${ }^{212}$ Most of the laws provide severe penalties for violations. In Florida, Missouri and Virginia, a lock-out or strike subjects the utility or the union to a penalty up to $\$ 10,000$ for each day of interruption of service. And any violation of the act by a union member acting in concert with others, or by any other individual, can result in imprisonment. In Florida, Michigan, Missouri, Nebraska, New Jersey and Pennsylvania, injunctions may be issued to enforce an order of an arbitration board.

A number of states have sought to cope with the problem of strikes in violation of a collective bargaining agreement. Legislation passed has been of three types. First, a specific exception is made in the anti-injunction act, as in Pennsylvania, ${ }^{213}$ to permit injunctions to issue in cases where a strike has been called in violation of a collective bargaining agreement. Second, laws have been enacted declaring such strikes illegal, and authorizing suit for damages or for an injunction. ${ }^{214}$ Third, Colorado, ${ }^{2 \times 5}$ Minne-

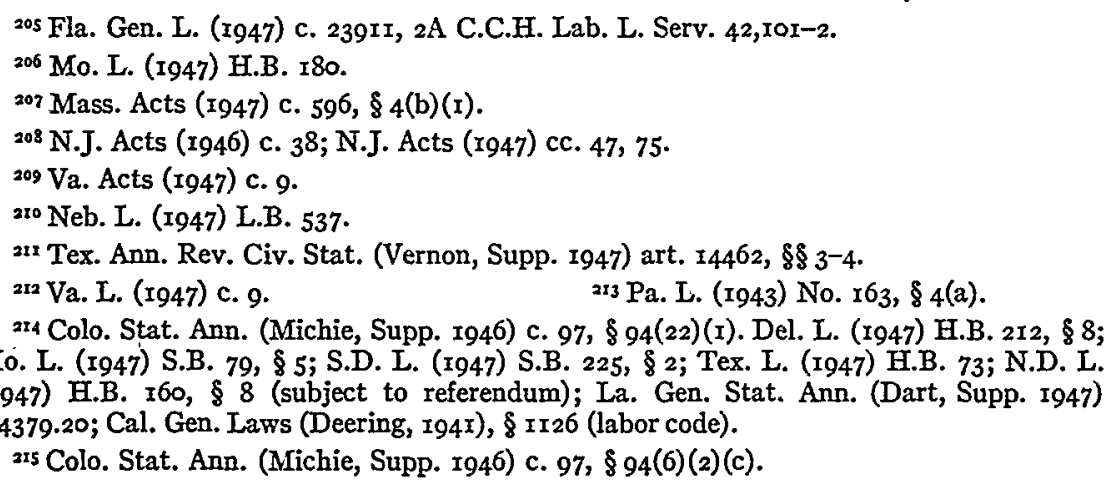


sota $^{216}$ and Wisconsin ${ }^{27}$ have made participation in such strikes an employee unfair labor practice.

The sit-down strike, once characterized by the Supreme Court as "a high-handed proceeding without shadow of legal right," 218 has been proscribed by statute in fourteen states. ${ }^{219}$ Strikes by public employees are prohibited by laws enacted in 1947 in Michigan, ${ }^{220}$ Missouri, ${ }^{221}$ New York, ${ }^{222}$ Ohio, ${ }^{223}$ Pennsylvania ${ }^{224}$ and Texas. ${ }^{225}$ Most of these laws provide that a violation of the act will result in termination of employment and deprivation of governmental employment rights. In Missouri, a public employee who engages in a strike is guilty of a misdemeanor. ${ }^{226}$ Minnesota forbids strikes or lock-outs in charitable hospitals. ${ }^{227}$

\section{JURISDICTIONAL DISPUTES}

A jurisdictional dispute usually involves a controversy between two or more labor organizations over the right of representation or jurisdiction over particular work. Laws regulating or prohibiting strikes in connection with jurisdictional disputes have been enacted in California, ${ }^{228}$ Florida, ${ }^{229}$ Kansas, ${ }^{230}$ Massachusetts, ${ }^{231}$ Michigan, ${ }^{232}$ Minnesota, ${ }^{233}$ Missouri, ${ }^{234}$ Oregon, ${ }^{235}$ Pennsylvania ${ }^{236}$ and Wisconsin. ${ }^{237}$ The Florida statute makes it un-

${ }^{216}$ Minn. Stat. (Henderson, I945) \& $\mathrm{x}$ 79.xI(I).

${ }^{217}$ Wis. Stat. (Brossard, I943) $\S$ Irr.06(2)(c).

${ }_{218}$ NLRB v. Fansteel Metallurgical Corp., 306 U.S. 240, 252 (1939).

${ }_{219}$ Colo. Stat. Ann. (Michie, Supp. 1946) c. 97, § 94(6)(2)(i); Del. L. (1947) c. 196, 2(H); Fla. Gen. I. (1943) c. $2 \times 968, \S 9(7)$; Kan. L. (1943) c. I9r, \& I3; La. Gen. Stat. Ann. (Dart, Supp. 1947) §4379.22(b); Md. Ann. Code (Flack, Supp. I943) art. 27, § 24A; Mass. Ann. Laws (1942) c. 150a, $\$ 4$ A; Mich. Stat. Ann. (Henderson, Supp. I946) § I 7-454-15; Minn. Stat. (Henderson, I945) § I79.II (3); Pa. Stat. Ann. (Purdon, I94r) tit. 43, \& 21r.6(2)(b); Utah L. (r947) H.B. 36, $\$ 49^{-1-16(2)(f) ; ~ V t . ~ A c t s ~(1937) ~ N o . ~ 210, ~ a t ~ 25 r ; ~ W a s h . ~ R e v . ~ S t a t . ~}$ Ann. (Remington, x932) § 2563-4; Wis. Stat. (Brossard, x943) § IIr.06 (2)(h).

220 Mich. Pub. Acts (1947) No. 336, 20 L.R.R.M. 3095.

${ }_{22}$ Mo. L. (1947) S.B. 79, §7, 20 L.R.R.M. 3093.

${ }_{222}$ N.Y. L. (1947) c. 39x, 20 L.R.R.M. 300 I.

22320 L.R.R.M. 3072 (1947).

22420 L.R.R.M. 3065 (1947).

255 20 L.R.R.M. 3014 (I947).

${ }_{206}^{20}$ Mo. L. (1947) S.B. 79, § 7 .

${ }^{227}$ Minn. L. (I947) c. 335,20 L.R.R.M. 3013.

288 Cal. Stat. (r947) c. 1388, 20 L.R.R.M. 3077 .

229 Fla. Gen. L. (r943) c. 21968, §9(ro).

${ }^{230} \mathrm{Kan}$. L. (r943) c. rgr, $\$ 8\left(\mathrm{I}_{3}\right)$. Held unconstitutional in Stapleton v. Mitchell, 60 F. Supp. 5I (Kan., I945)

${ }_{231}$ Mass. Acts (1947) c. $657, \S 5$ (c).

${ }_{232}$ Mich. Pub. Acts (1947) No. 3 r8, § gc.

${ }_{233}$ Minn. Stat. (Henderson, $x_{945)} \&$ I79.083.

${ }_{234}$ Mo. L. (I947) S.B. 79, \$6(2).

${ }_{235}$ Ore. Comp. Laws Ann. (1940), §102-906. Invalidated in AFL v. Bain, r65 Ore. 183 , I06 P. 2d 544 (x940).

${ }^{236} \mathrm{~Pa}$. L. (1947) Act No. $55^{8}, \S 6(2)(1) . \quad \quad{ }^{237}$ Wis. L. (1947) c. $53^{\circ}, \S \operatorname{Ir} 1.06(2)(\mathrm{e})$. 
lawful "to interfere with work by reason of any jurisdictional dispute, grievance or disagreement between or with a labor organization." Minnesota's approach is more constructive, for not only does it prohibit a jurisdictional strike, but a procedure is provided for settlement of such disputes. After the state's labor conciliator has certified a jurisdictional dispute to him, the governor is empowered at his discretion - unless the parties agree to some form of private arbitration - to appoint a "labor referee" to resolve the controversy "in accordance with the proper construction of the agreement or of the provisions of the charters of the contending organizations, or, in the absence of such guides, in a way that will promote industrial peace." After a referee has been appointed to settle a jurisdictional dispute, any strike, picketing or boycotting arising out of the dispute becomes unlawful. Pennsylvania, ${ }^{238}$ Colorado $^{239}$ and California ${ }^{240}$ permit the issuance of an injunction under such circumstances, and, in addition, California permits the recovery of damages incurred. Michigan ${ }^{24 x}$ and Massachusetts ${ }^{242}$ provide for voluntary settlement, but, in the latter state, after the parties have submitted an issue to arbitration and one of them fails to comply with the terms of the award, an injunction may be obtained to prevent a strike, picketing, boycott, or other concerted interference against an employer. The Missouri law provides that the parties have the duty to settle, if necessary by arbitration, and where they fail to follow this procedure, the industrial commission, upon application of any of the parties, may make a binding determination of the dispute. ${ }^{243}$ Participation in a jurisdictional strike is made an unfair labor practice in Pennsylvania ${ }^{244}$ and Wisconsin. ${ }^{245}$

\section{CONTRACT RESPONSIBILITY}

At common law a union, as a voluntary, unincorporated association, could neither sue nor be sued in its own name. Only the members of the union, as individuals, were subject to judicial proceedings. Much has been made of the fact that an employer, who entered a collective bargaining agreement, has often been unable to sue the contracting union for breach of contract because the labor organization was not recognized as a legal entity. A number of states have by statute sought to improve this situation. Three states have included provisions in their labor relations acts

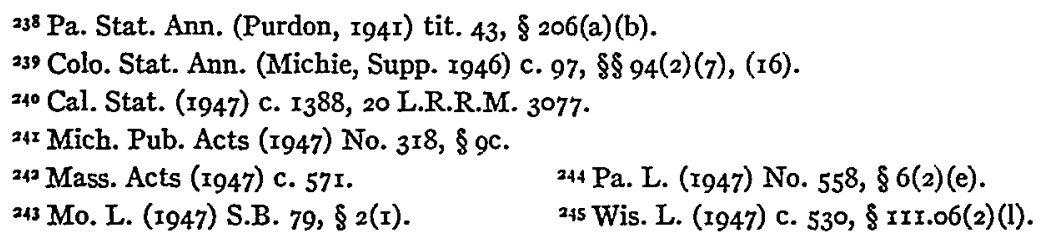


making it an unfair labor practice for either an employer or an employee to violate a collective bargaining agreement. ${ }^{24}$ The Delaware law, however, makes it an unfair labor practice only for employees to do so. ${ }^{247}$ In addition to extensive legislation resulting from a change from the English concept that a collective bargaining agreement is not enforceable at law, thirteen states have indirectly legislated on this problem by specifically providing for the suability of unions under certain circumstances. ${ }^{248}$ For example, the Louisiana statute provides: "Both labor organization and employer shall be bound by the acts of its duly authorized agents and may sue or be sued as an entity and in behalf of those whom they represent in the courts of the State of Louisiana, provided, that any money judgment against such labor organization, whether under this section or otherwise, shall be enforced only against the organization as an entity and against its assets and funds, and shall not be enforceable against the property of an individual member." ${ }_{249}$ The California statute provides more directly for contract responsibility, in these words: "Any collective bargaining agreement between an employer and a labor organization shall be enforceable at law or in equity and a breach of such collective agreement by any party thereto shall be subject to the same remedies, including injunctive relief, as are available on other contracts in the courts of this state. ${ }^{250} \mathrm{~A}$ frequently-found provision in state suability statutes specifies that unions are responsible for the actions of their authorized representatives. ${ }^{25}$ Under the Texas law a union whose members engage in picketing or a strike are liable for damages in the event such picketing or strike is held to be a breach of contract. ${ }^{252}$

The broad provision for suability in federal courts incorporated in the Taft-Hartley Act ${ }^{253}$ is likely to obviate the need for state legislation in this regard.

A generation or so ago there was a considerable demand that unions should be required to incorporate. With the recent trend toward permit${ }^{246}$ Colo. Stat. Ann. (Michie, Supp. x946) c. $97, \$ \$ 94(6)(2)(c),(22)(1)$; Minn. Stat. (Henderson, 1945) § I79.rx(1); Wis. Stat. (Brossard, I943) \& III.06(2)(c).

247 Del. L. (I947) H.B. 212, $\$ 2$ (c).

${ }^{248}$ Ariz. L. (I947) c. 8I, §6; Cal. Gen. Laws (Deering, r94I) § II26 (labor code); Del. L. (1947) H.B. 2I 2, § 8; Fla. Gen. L. (r943) c. 21968, § II; Kan. L. (I943) c. I9I, § Io; La. Gen. Stat. Ann. (Dart, Supp. T947) \$4379.20; Minn. L. (I947) c. 527, 20 L.R.R.M. 3009 ; Neb. L. (1947) L.B. 276 , 20 L.R.R.M. 3067 ; N.C. L. (1947) c. 328, \$ 6, Ig L.R.R.M. 3036; N.D. L. (r947) H.B. r6o, $\S 8$ (subject to approval at referendum); S.D. L. (r947) S.B. 225, § I; Tex. L. (1947) H.B. 73, § I, 20 L.R.R.M. 301 7; Va. L. (1947) H.B. 5, C. 2, § 6, I9 L.R.R.M. 3023.

${ }_{249}$ La. Gen. Stat. Ann. (Dart, Supp. 1947) § 4379.20.

${ }^{250} \mathrm{Cal}$. Gen. Laws (Deering, I94I) $\S$ II26 (labor code).

${ }_{25 \mathrm{r}}$ See, e.g., Del. L. (I947) c. I96, \&8. ${ }_{250}$ Tex. L. (1947) H.B. 73, § I.

${ }^{253}$ Labor-Management Relations Act, 29 U.S.C.A. $\$ 185$ (I947). 
ting suits for damages to be brought against unions, little more than an echo of the movement for compulsory incorporation has survived. This was in Colorado where such a statute was enacted in I943; but it was subsequently held to be unconstitutional on the ground that incorporation is a voluntary act, and, as applied here, the provision deprived unions and their members of their liberty and their civil rights without due process of law, in violation of the First and Fourteenth Amendments. ${ }^{254}$

\section{POLITICAI CONTRIBUTIONS}

In response to increasing interest in political action by unions, five states, ${ }^{255}$ as well as the federal government, ${ }^{256}$ have prohibited political contributions by labor organizations. The Texas statute declares that "It shall be unlawful for any labor union to make a financial contribution to any political party or person running for political office." 257 The Delaware act specifically includes within the prohibition not only the making of such contributions, but also the soliciting of funds by a union for political purposes. But, on the other hand, the Supreme Judicial Court of Massachusetts held that an initiative measure prohibiting political activity by labor unions would be unconstitutional if enacted. ${ }^{258}$ Accordingly, the petition was not submitted to a vote of the electorate.

\section{THE REGULATION OF IABOR UNIONS}

Increasing legislative interest has been manifest in recent years not only in the methods used by unions, but also in the labor organization itself. Thus, statutes have been enacted providing for registration and financial reports, the regulation of union elections and membership practices, and the registration or licensing of union agents.

\section{UNION REGISTRATION AND FINANCIAL REPORTS}

Eleven states have adopted statutes requiring some type of registration. ${ }^{259}$ The Alabama statute is typical. It requires the filing of the follow-

${ }^{254}$ AFL v. Reilly, I13 Colo. 90, I55 P. 2d I45 (r944), holding unconstitutional Colo. Stat. Ann. (Michie, Supp. I946) c. $97, \$ 94$ (20).

2ss Ala. Gen. Acts (1943) No. $298, \S I_{7}$, at 258 , invalidated on procedural grounds in AFL v. McAdory, 246 Ala. I, I8 So. 2d 810 (1944); Colo. Stat. Ann. (Michie, Supp. 1946) c. 97, $\$ 94(20)(4)(c)$, invalidated because an earlier provision in the section was held to be unconstitutional; Del. L. (1947) c. I96, \& 23; Pa. L. (1943) No. 358; Tex. L. (I943) c. I04, §4(b).

${ }_{256}$ Labor-Management Relations Act, 2 U.S.C.A. \$ 251.

${ }_{257}$ Tex. L. (I943) c. I04, $\$ 4$ (b).

${ }^{258}$ Bowe v. Commonwealth, 69 N.E. $2 \mathrm{~d}$ II5 (Mass., 1946).

${ }^{259}$ Ala. Gen. Acts (1943) 255, $\S 7$; Colo. Stat. Ann. (Michie, Supp. 1946) c. 97, $\S 94(20)(\mathrm{I})$ (invalidated); Del. L. (1947) c. I96, $\$ \S$ I x-12; Fla. Gen. L. (1943) C. 21968, $\$ \$ 4$, IO; Idaho Laws (1943) c. 76, \& I, invalidated on procedural grounds in AFL v. Langley, 66 Idaho 763 , I68 P. 2d 83I (1946); Kan. L. (I943) c. I9I, § 5(3); Mass., 2A C.C.H. Lab. L. Serv. 43,575; N.H. L. (1947) c. I94, \& 2I-b (applies only to unions with union-security contracts); N.D. L. (1947) 
ing information annually with the state department of labor: I) the name of the labor organization, the location of its principal office and its offices of the state; 2) the names and addresses of its officers and business agents, together with the salaries and other remuneration paid each;3) the date of regular election of officers and the number of its paid-up members; 4) a complete financial statement of all fees, dues, fines or assessments levied and received, together with an itemized list of all disbursements, with names of recipients and purpose thereof, covering the preceding twelve months; 5) a complete statement of all property owned by the labor organization, including any monies on hand or accredited. ${ }^{260}$

One of the reasons which unions have given for opposing such statutes is that if the employer is able to obtain a statement of the union's financial resources, he will then be better able to break a strike by coldly calculating how long the union will be able to hold out. As regards secrecy requirements, Texas and Delaware make such reports available only to state officers and commissions; Alabama, in addition, makes the reports available to members of the union; but Florida, Kansas, Massachusetts and North Dakota specify that such reports shall be available for public inspection, while Idaho, South Dakota and Utah are silent upon the availability of the reports. The information required for registration in Utah is not, however, of a confidential nature. New Hampshire requires a financial report only when the union has entered into a union-security contract with the employer. Minnesota and Wisconsin require the officers to furnish financial statements to all union members. Delaware, Florida and Texas require that account books be open to inspection by union members at reasonable times.

\section{REGULATION OF UNION ELECTIONS}

The Minnesota Labor Union Democracy Act of $1943^{26 x}$ sets out its own justification in this excerpt from its preamble:

Whereas it is well recognized that the majority of labor unions are organized and operated upon democratic principles so that their officers and representatives are responsible and responsive to their members, and

Whereas disregard of democratic principles in the case of some unions has resulted in a denial of the rights of their members and in labor disputes and controversies affecting the public interest, and

Whereas undemocratic organization or operation of labor unions is inimical to the best interests of the members thereof and is contrary to the public welfare: ....

H.B. I60, §§ 2-3 (subject to approval at referendum); S.D. I. (I943) c. 86, § I; Tex. Ann. Rev. Civ. Stat. (Vernon, Supp. 1946 ) tit. 83 , art. 5154a, $\$ 3$.

260 Ala. Gen. Acts (1943) 255, \&7.

26x Minn. Stat. (Henderson, I945) § I79.19-20. 
The act which follows requires unions to hold elections at least every four years by secret ballot and after reasonable notice. In addition, Delaware ${ }^{262}$ and $\mathrm{Texas}^{26_{3}}$ have comparable requirements. However, the Texas law ${ }^{264}$ requiring annual union elections was held invalid because its exceptions were deemed discriminatory. ${ }^{265}$ Delaware requires certification of the election results by a disinterested person and permits anyone dissatisfied to petition a court of equity for a review of the entire proceeding. ${ }^{266}$

\section{REGISTRATION, LICENSING OR OTEER RESTRICTIONS ON UNION AGENTS}

Florida ${ }^{267}$ and Kansas ${ }^{268}$ have enacted statutes requiring the licensing of paid union representatives. The Florida law, in addition to the requirement that applicants be citizens of the United States, provides that no license shall be issued to one who has been convicted of a felony, or who is not a person of good moral character. A Texas statute requires that all paid union organizers must obtain, in advance of solicitation, an organizer's card from the Secretary of State. ${ }^{269}$ Issuance of a license is discretionary with state officials only in Florida; ${ }^{270}$ in Texas and Kansas it is mandatory. In Alabama filing by the union of the required annual report with the state is a condition precedent to the lawful collection of "dues, assessments, or any other monies from any member" by an officer or agent of the labor organization..$^{27}$

\section{RACLAL AND RELIGIOUS DISCRIMINATION}

State legislatures have attacked the problem of discrimination in many ways. Laws in Connecticut, ${ }^{272}$ Massachusetts, ${ }^{273}$ New Jersey ${ }^{274}$ and New York $^{275}$ now make it illegal for any union or employer to discriminate

${ }^{202}$ Del. L. (I943) C. I96, \& 2 I.

${ }^{263}$ Tex. Ann. Rev. Civ. Stats. (Vernon, Supp. 1946) tit. 83 , art. 5154a, $\$ 4 a$.

${ }^{264}$ Tex. Ann. Rev. Civ. Stats. (Vernon, Supp. 1946) tit. 83 , art. 5154a, $\$ 3$.

${ }^{265}$ AFL v. Mann, I88 S.W. $2 d 276$ (Tex. Civ. App., 1945).

${ }^{266}$ Del. L. (I947) C. I96, § I9.

${ }^{267}$ Fla. Gen. L. (I943) c. 2Ig68, $\S \S 4$, IO.

${ }^{268} \mathrm{Kan}$. L. (I943) C. I9I, $\S 5(3)$.

${ }^{269}$ Tex. Ann. Rev. Civ. Stats. (Vernon, Supp. I946) tit. 83, art. 5154a, §3. The licensing provision was held to be unconstitutional as applied to a speech soliciting membership. Thomas v. Collins, 323 U.S. $5^{16}$ (I944).

${ }^{270}$ This section was invalidated insofar as it applied to employees who fall within the jurisdiction of the National Labor Relations Act. Hill v. Florida, 325 U.S. 538 (1944).

${ }^{27 x}$ Ala. Gen. Acts (r943) 255, \& 7 .

${ }^{272}$ Conn. Spec. L. (1947) P.A. I7r.

${ }_{273}$ Mass. Acts (1946) c. 368.

${ }^{274}$ N.J. Rev. Stat. (Supp. I945) tit. 18, c. 25, \& 18.25-r2(b).

${ }_{275}$ N.Y. L. (I943) C. I18, art. I2. 
against an employee because of his race, color or creed, and they provide means for enforcement through administrative agencies. Kansas ${ }^{276}$ and Nebraska ${ }^{277}$ deny collective bargaining privileges to unions which so discriminate. A union practicing racial discrimination cannot in Pennsylvania qualify as a labor organization under the state labor relations act. ${ }^{278}$ Wisconsin has lodged in its industrial commission the power to investigate the existence, character, causes and extent of discrimination, but the commission is given no powers of compulsion. ${ }^{279}$ The Colorado Labor Peace Act of 1943 declares that "No person shall be denied membership in a labor organization or union on account of race, color, religion, sex or by any unjust discrimination. ${ }^{280}$ However, no specific penalties are set forth.

The above sets out the chief explicit controls of labor relations and union organization and activities appearing in state laws during the last ten years. While the control sought is not by any means all new, this analysis indicates which way the wind has been blowing in various parts of the United States. It is still too early to observe the effect of restrictive statutes on union development and the collective bargaining process, but in light of the prevalence of such legislation, it remains a vital question. The Taft-Hartley Act will of course tend to make the pattern of restrictive statutes more nearly uniform, but in many vital areas of union control some of the state statutes go well beyond the federal act. In the meantime, how much of the state legislation will survive court tests and our experience in the realm of labor-management relations remains to be seen.

${ }_{276} \mathrm{Kan}$. Gen. Stat. (Corrick, Supp. I94I), \$ 44-80I.

277 Neb. Rev. Stat. (1943) \& 48-2r4.

${ }_{278}$ Pa. Stat. Ann. (Purdon, Supp. I946) tit. 43, §2rr.3(f).

${ }^{279}$ Wis. L. (I945) 86r, C. 490 , § Irr.35.

${ }^{280}$ Colo. Stat. Ann. (Michie, Supp. 1946) c. 97, § 94(I)(4). 